\title{
Technology Implication of Agricultural Sectors in China: A CGE Analysis Based on CHINAGEM Model
}

\author{
Syed Shoyeb Hossain ${ }^{1} \&$ Huang Delin ${ }^{1}$ \\ ${ }^{1}$ The Institute of Agricultural Economics and Development, The Chinese Academy of Agriculture Sciences, \\ Beijing, China \\ Correspondence: Huang Delin, The Institute of Agricultural Economics and Development, The Chinese \\ Academy of Agricultural Sciences, 12 Zhongguancun Nandajie, Haidian District, Beijing, 100081, China. Tel: \\ 86-10-8210-6167; 186-1210-5186. E-mail: huangdelin@caas.cn
}

Received: August 2, 2019

doi:10.5539/jas.v11n17p75
Accepted: September 4, $2019 \quad$ Online Published: October 15, 2019

URL: https://doi.org/10.5539/jas.v11n17p75

The research is financed by project of "Open Laboratory of national agricultural policy analysis and decision support system-The platform Construction of the agricultural strategic analysis and its expansion, opening and communication for "Belt and Road Initiative". Y2018PT31, 2018"; "Construction of Portal and Platform of Agricultural Economic Theory, Policy Analysis and remote Scientific Research Environment. 161005201902-1 2019”.

\begin{abstract}
The primary goal of Chinese agricultural development is to guarantee national food security and the supply of major agricultural products. Hence, the improvement of agricultural technology plays a vital role in China for economic development. Technological change in agricultural sector results in higher future economic growth as well as food security, both in food consumption and availability. By constructing China's agriculture general equilibrium model (CGE), this paper explains the impact of agricultural technology change. This paper constructs a dynamic CGE model based on CHINAGEM model for analyzing the technology increase in China Agricultural sector and then describes the construction of database and policy scenario. Model such as Computable General Equilibrium (CGE) model is used to conduct analysis of the economy-wide impacts of new agricultural technologies in China. In the general equilibrium model, some external variables are established; any part of structural changes caused by its exogenous variables can affect the entire system, resulting in general changes of goods, prices and quantity of factor. Simulation result of this paper indicates the agriculture sector output increases respectively; employment decreases; production cost decreases; and investment increases. Finally this paper describes the effects of the policy of technology changes by comparing policy scenario to baseline scenario and explains the impact of technology changes in China economy using CHINAGEM model.
\end{abstract}

Keywords: dynamic Computable General Equilibrium (CGE) Model, MONASH Model, changes in technology, China

\section{Introduction}

Historically, China was a great agriculture-dominated nation, with splendid techniques and high land productivity in the world. However, for many reasons, China was left far behind in agricultural production, science and technology in the past two centuries. Since the foundation of PRC in 1949, a huge agricultural technology innovation system was set up and agricultural production was largely developed. Especially under the opening and reform policies of the 1980s and 1990s, the agricultural sector of China grew rapidly. It has not only provided adequate food stuff to the large people, but also played important role in the national economic development. China's pursuit of socialist collectivization, focusing mainly on heavy industries since the early 1950s, had given way to economic reform in 1978, and the primary industry played important role in economic development. Since the mid-1980s China had taken various economic activities such as rural township and village-owned enterprises development to provide a better market environment through domestic market reform, fiscal and financial initiatives, the devaluation of the exchange rate, trade liberalization, the expansion of special economic zones to attract foreign direct investment (FDI), state-owned enterprise (SOE) reform, agricultural trade liberalization and many other policies, China economy made great achievements. Since then Chinese agriculture 
has been keeping high growth rates, and successfully fed the largest and continuously increasing population in the world. The improvement of yields from agricultural crop is the only means to break the constraints of land resources and achieve sustainable agricultural growth in China. The income of farmers in China has been growing very fast so far. It has changed the livelihoods of a lot of poor farmers. The poverty rate in rural China has been substantively decreasing in the past years. Recent data from the National Bureau of Statistics showed, over the past six years China has upraised 82.39 million rural poor out of poverty. The proportion of people living below the poverty line dropped from 10.2 to 1.7 percent in the same period. According to National Bureau of Statistics, the poverty rate of the people living in rural area in 2018 was 1.4 percentage points lower than 2017 (China Daily 2019). Technological change has played a major role in the development of the agricultural sector in China. China has a large agricultural sector and large food economy. Although agricultural growth has been lower than the growth in the rest of economy, its performance has been impressive since late 1970s. After 1978, de-collectivization, price increases, and the relaxation of domestic trade restrictions on most agricultural products accompanied the take-off of China's food economy. During the reform period there are several factors that have simultaneously contributed to agricultural production growth. The reform of Agricultural sector resulted in increase in agricultural production, increase in food consumption quality and quantity, and reduction of poverty. Household responsibility system (HRS) was among a system of Agricultural reform in China and a policy that gave individual farmers control and income rights in agriculture. Household responsibility system in the early 1980s was an agriculture production system, which allowed households to contract land, machinery and other facilities from collective organizations. In this system households could make operating decisions independently. HRS spread nationwide with the support of the central government and by 1983 more than 93 percent of production teams had adopted the system. Some studies indicate that since the HRS was completed in 1984, technological change has been the primary engine of the agricultural growth. Improvements in technology have by far contributed the largest share of crop production growth even during the early reform period. China's agricultural research is entirely dominated by the State and Chinese state is spending significantly large sums of money on agricultural R\&D projects. According to the Chinese Academy of Sciences, in 2016 government spending on R\&D was 2.1 per cent of GDP, reaching 1.54 trillion yuan (\$296 billion). China is one of the only countries in the world in which agricultural R\&D expenditures as a share of Agricultural GDP is rising. According to BEIJING (Reuters), the Agricultural Development Bank of China, one of the country's main policy lenders, agreed to loan at least 3 trillion yuan ( $\$ 450$ billion) by 2020 for the modernization of China's agriculture industry. Moreover China is investing in far more than conventional agricultural technology. China's agricultural leaders believe that investments in agricultural R\&D will play an important role in driving agricultural output in the future. Therefore this paper focuses on technology implication on Agricultural sector and its influencing factors in China economy using CGE analysis. This paper proposed to run a policy simulation of technology increase on agricultural sector and explained the effects of economy, and finally give details analysis whether it has advantage to introduce new technology in agricultural sector or not. The rest of this paper explains methodology and the main model, and policy simulation scenario. Finally this paper builds a conclusion based on policy simulation results and give future suggestions.

\section{A CGE Model for Analyzing Technology Implication}

\subsection{Background of China General Equilibrium Model}

The thought of CGE model came from the general equilibrium of Walrasian Theory, commonly used to analyze taxes, changes in public consumption, tariffs and other foreign trade policies, technology changes, environmental policies, wages, the welfare of a country or region (domestic or transnational), industrial structure, labor market, environment condition, and income distribution effect. CHINAGEM is a recursive dynamic CGE model was developed from the Monash model (Dixon \& Rimmer, 2002). Since the 1990s, the MONASH model has been applied in economic policy analysis on a broad range of issues in Chinese economy such as to analyze tax reform; contributions of various economic sectors; fiscal relationships between federal and regional governments; forecasting greenhouse gas emissions, regional employment; employment and wage policies; and macroeconomic policies. In the past decade, other countries have been developing their own dynamic CGE models using MONASH model. US, Finland, China, Vietnam, Malaysia and Poland have already applied MONASH-style dynamic models for policy analysis. Currently, the research field of CGE model application in China is mainly focus on several aspects such as, (1) International trade policy, especially study of tariff and non-tariff barrier policies, (2) Economic reforms and economic development policy studies, (3) Macroeconomic policies, especially tax policy, and (4) micro-industry policy. Although in recent years in China there has been a rapid development in CGE research, but overall, using CGE to analyze changes in technology in agricultural sectors there has made a little contribution from researchers. The model used in this paper for analyze the 
technological implication in Chinese Agriculture is CHINAGEM (China Agricultural) model. CHINAGEM is a MONASH-style dynamic Computable General Equilibrium (CGE) model of China. This model is widely used for estimating changes in technology, generating up-to-date input-output table, forecasting policy changes etc. CHINAGEM is a wide-ranging system which followed by lot of equations describing the behaviors of economic agents and linkages between different sectors of the economy and between China and the rest of the world. CHINAGEM simulations start from a base year 2002 and the year 2002 input-output table is used to construct the model database that depict a concept of the Chinese economy for that year. The model database provides an initial solution for the CHINAGEM equation system and simulation moves each of the components of the input-output database. The core part of CHINAGEM contains widely accepted economic theories such as consumer and producer optimization behavior. China's agriculture CGE model is divided into 137 sectors and products, 10 kinds of labor (agricultural employment, rural non-farm employment, migrant workers, urban low-skill, high-skilled urban, agricultural unemployment, unemployment of migrant workers, urban unemployment, the new rural labor force, added urban workforce,). Variables in CHINAGEM are larger than the number of equations. CHINAGEM variables are flexible, one variable can be endogenous in one simulation and other simulation can be exogenous. In CHINAGEM, historical and forecast simulations form a baseline scenario and policy simulation scenario shows the effects of a change in economic policy. Therefore this paper explains what will happen to economy when there is technological change or shock? Or it can be said the technology is expected to grow specific percentage set by simulation then what happen to macro-economy, agricultural sectors and overall investment?

\subsection{Model Database}

Database of China's agricultural CGE model came from the input-output table in 2002, the national budget, the final statement of income and expenditure, and the balance of payments. The model database is built mainly based on the Weighted Average Mark (WAM) method of Monash University in Australia. The basic steps for building a model database include building a product flow matrix, a tax matrix, and a circulation expense matrix, and also performing the necessary summation and splitting of the industrial sectors based on the 2002 input-output table. Figure 1 shows the structure of the CHINAGEM input-output database. CHINAGEM input-output database consists of three parts such as absorption matrix, joint-production matrix and a vector of import duties. In the absorption matrix the first row from V1BAS to V6BAS shows flows in year $t$ of commodities to producers, investors, households, exports, public consumption and inventory accumulation. Each of matrices has $\mathrm{C} \times \mathrm{S}$ rows, one for each of $\mathrm{C}$ commodities from $\mathrm{S}$ sources. $\mathrm{C}$ is the number of commodities in the model (e.g., 137 for the year 2002 database) and S is 2 sources (domestic and imported). In the database V1BAS and V2BAS each have/columns where/stands for the number of industries (137 for the 2002 database). On the other hand V3BAS to V6BAS each have one column. In the input-output database, no imported commodity is exported without being processed in a domestic industry and V4BAS $(\mathrm{c}, \mathrm{s})$ is zero wherever $\mathrm{s}=$ "imp". All of the flows from V1BAS to V6BAS are valued at basic prices. The basic price of a domestically produced good ( $\mathrm{s}=$ "dom") is the price received by the producer and the basic price of an imported good is the landed-duty-paid price. The margin matrices from V1MAR to V6MAR show the values of $\mathrm{N}$ margin commodities used in facilitating the flows identified in V1BAS to V6BAS. For the 2002 database, $\mathrm{N}=8$ where $\mathrm{N}$ stands for number of commodities. In the database imports are not used as margin services. Each of the matrices from V1MAR to V6MAR has $\mathrm{C} \times \mathrm{S} \times \mathrm{N}$ rows. V1MAR and V2MAR have/columns identifying industrial producers and industrial capital creators, and V3MAR to V6MAR each have one column. All the flows in the MAR matrices as with the BAS matrices are valued at basic prices. 


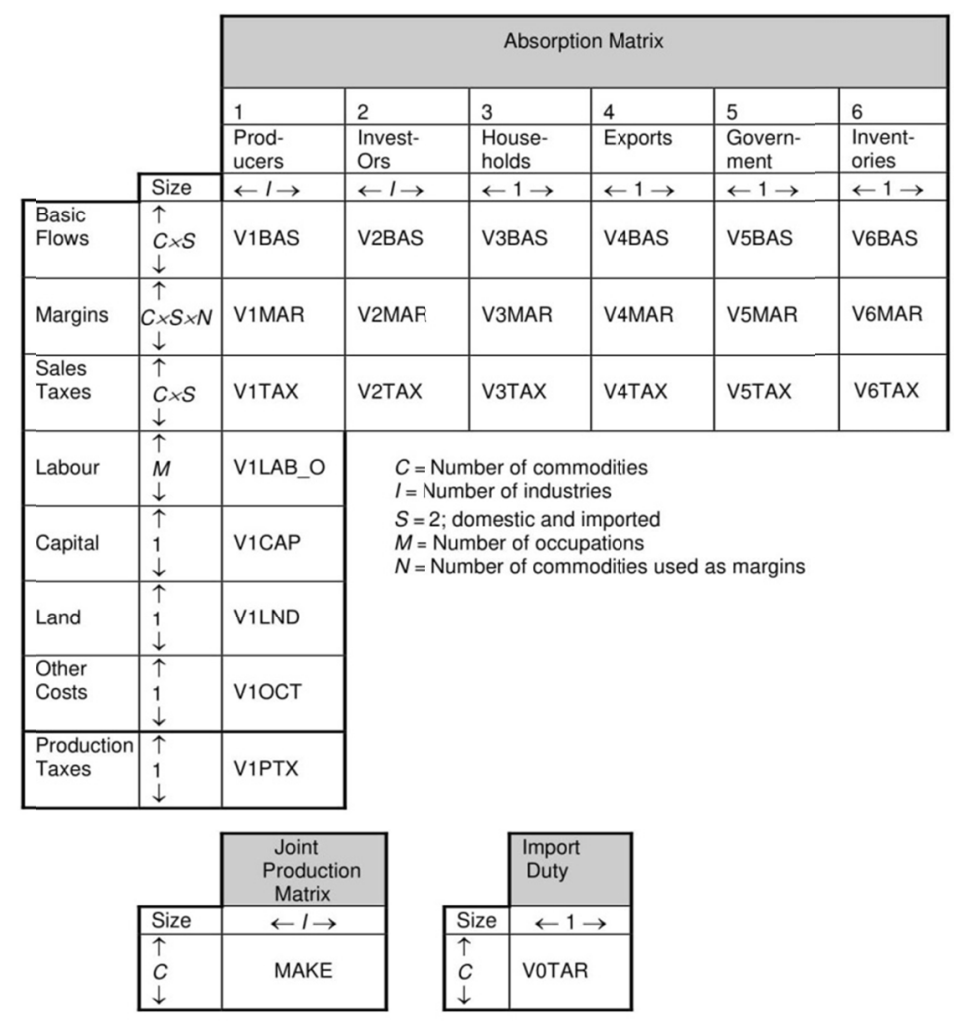

Figure 1.The CHINAGEM input-output database

Source: Mai, Dixon, and Rimmer (2010).

V1TAX to V6TAX record collections of sales taxes and entries in these matrices show sales taxes. In the CHINAGEM model for inventory accumulation there are no sales taxes so V6TAX does not appear in the TABLO code. Most of the entries in sales-tax matrices are non-negative and it is possible to use negative entries to represent subsidies. In the CHINAGEM database, the ratio of $\operatorname{V1TAX}(\mathrm{c}, \mathrm{s}, \mathrm{i})$ to $\operatorname{V1BAS}(\mathrm{c}, \mathrm{s}, \mathrm{i})$ may differ from the ratio of $\operatorname{V3TAX}(\mathrm{c}, \mathrm{s})$ to $\mathrm{V} 3 \mathrm{BAS}(\mathrm{c}, \mathrm{s})$. There may also be differences in the sales tax rates as implied by the database on flows of (c,"dom") and (c,"imp") to the same users. Matrix V1LAB_O records payments by industries for labour. The vectors V1CAP and V1LND show payments by industries for their use of fixed capital and land. The current database of CHINAGEM shows non-zero land rentals for agricultural and mining industries. Other industries are treated as though they use no scarce land. The vector V1OCT records other costs incurred by industries and the vectors V1PTX show collections of taxes on production. The final two data sets are VOTAR and MAKE. V0TAR is a $\mathrm{C} \times 1$ vector shows tariff revenue by imported commodity. On the other hand the joint-product matrix MAKE has dimensions $\mathrm{C} \times /$. Together, the absorption and joint-production matrices satisfy two balance conditions. First, the column sums of MAKE, are identical to the values of industry inputs. Second, the row sums of MAKE, are identical to basic values of demands for domestic commodities. An implication of the two balance conditions is that the total value of inputs to domestic production equals the total value of demands for domestic products:

$$
\begin{aligned}
& \text { Sum } \left.(\text { V1BAS })+\text { Sum }(V 1 M A R)+\text { Sum }(V 1 T A X)+\text { Sum }\left(V 1 L A B \_O\right)+\text { Sum (V1CAP }\right)+ \text { Sum (V1LND) + } \\
& \text { Sum }(\text { V1OCT })+\text { Sum }(\text { V1PTX })=\text { Sum }(\text { V1BAS })+\text { Sum }(\text { V2BAS })+\text { Sum }(\text { V3BAS })+\text { Sum }(V 4 B A S)+ \\
& \text { Sum }(\text { V5BAS })+\text { Sum }(\text { V6BAS })+\text { Sum }(\text { V1MAR })+\text { Sum }(V 2 M A R)+\text { Sum }(V 3 M A R)+\text { Sum }(V 4 M A R)+ \\
& \text { Sum }(\text { V5MAR })+\text { Sum }(\text { V6MAR })-[\text { Sum }(\operatorname{V1BAS}(\mathrm{imp}))+\text { Sum }(\text { V2BAS(imp }))+\text { Sum }(\text { V3BAS(imp }))+ \\
& \text { Sum (V4BAS(imp)) + Sum(V5BAS(imp)) + Sum(V6BAS(imp))] }
\end{aligned}
$$

Where, $\operatorname{Sum}(\mathrm{X})$ is the sum of all the components in the matrix X. CHINAGEM input-output database satisfies the national income identity: GDP from the income side equals GDP from the expenditure side. The similarity is established by cancelling Sum(V1BAS) and Sum(V1MAR) from both sides of Equation (1) and by adding Sum(V0TAR) and Sum(V $\varphi$ TAX), where, $\varphi=2, \ldots 6$. 


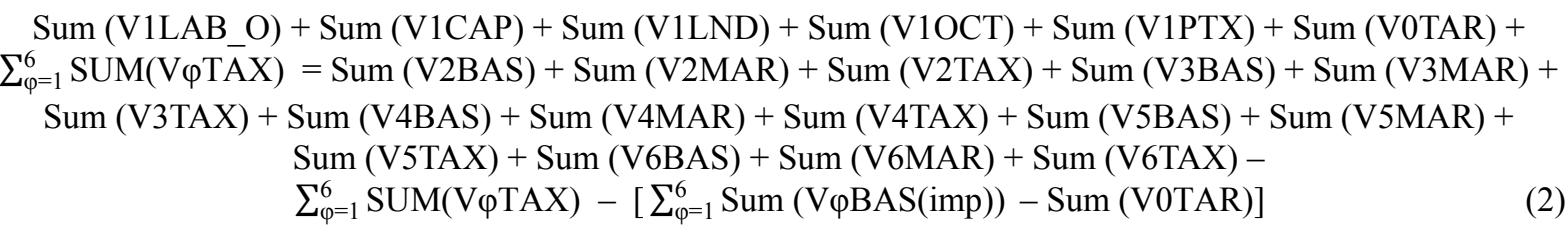

The left hand side is the income measure of the GDP and the right hand side is the expenditure measure of GDP.

\subsection{Model Policy Scenario}

In the agricultural CGE model, technological change means unit production. Investment in the technology is the input required for the change. In the CGE module, there are three levels of input technology, the first level is the input function of Lyontief production, and including the middle Inputs and basic inputs and other input technologies. Second level is a CES production input function that includes land, labor, and capital input technology. The third level is still the CES production input function including different types of labor input. In agriculture CGE model, technological change is the input, changes of per unit of output changes, it is the input technology. So production inputs function of Leontief at first-levels used to simulate the result. The Equation (3), of the Leontief's production function after adding the technical variables is as follows:

$$
X_{j}=\min \text { imum }\left(\frac{X 1_{j}}{A 1_{j}}, \frac{X 2_{j}}{A 2_{j}}, \ldots \frac{X n_{j}}{A n_{j}}\right)
$$

Where, $\mathrm{X}_{\mathrm{j}}$ is output, $\mathrm{X} 1_{\mathrm{j}}, \ldots \mathrm{X} \mathrm{n}_{\mathrm{j}}$ is input, $\mathrm{A} 1_{\mathrm{j}}, \ldots \mathrm{An} \mathrm{n}_{\mathrm{j}}$ is input technological change of each variable. As we can see, investment input is changed with its technology variable. When technology variable $\mathrm{A} 1_{\mathrm{j}}$ decline, equal the improvement of technical levels, therefore same output of $X_{j}$ will reduce the input investment of $X 1_{j}$. In the model, the equation of demand of intermediate input is:

$$
\mathrm{x} 1 \_\mathrm{s}(\mathrm{c}, \mathrm{i})-\left\{\mathrm{a} 1 \_\mathrm{s}(\mathrm{c}, \mathrm{i})+\mathrm{a} 1 \mathrm{tot}(\mathrm{i})\right\}=\mathrm{x} 1 \text { tot(i) }
$$

Where, $\left(\mathrm{x} 1 \_s(\mathrm{c}, \mathrm{i})\right)$ is quantity of intermediate inputs $\mathrm{c}$ needed by sector $\mathrm{i}, \mathrm{a} \_\mathrm{s}(\mathrm{c}, \mathrm{i})$ is the technology of intermediate inputs $\mathrm{c}$ needed by sector $\mathrm{i}$, altot(i) is the sector i's general technology intermediate inputs; $x 1$ tot(i) is the sector i's output quantity. It can be seen from the equation, if intermediate inputs technology used by sector $\mathrm{i}$ is improved to produce commodity $\mathrm{c}$, then variable a 1 s $\mathrm{s}(\mathrm{c}, \mathrm{i})$ will be shocked, if total intermediate inputs technology used by sector i is improved, then variable al tot(i) will be shocked.

In the main model, technology in agricultural crop like Soybean, Corn, Wheat, Rice, Millet and Vegetable has been increased to 25 percent to simulate and evaluate the impact of technology increase in China economy. It is assumed that from the period of 2020 to 2030 efficiency of technology will be improved from current condition and positively impact on China's economy and grain security. In the main model, in baseline scenario it has been shocked GDP, population, employment, activity level and other macro shock, and in policy scenario it has been shocked the exogenous variable named alprim which stands for all factor augmenting technical change. The computational approach for CHINAGEM depends on being able to solve the model. The model of this paper approaches year-to-year CHINAGEM simulations because it usually involves Johansen/Euler computations of the effects of relatively small movements in the exogenous variables. Euler solution method eight-step computation is made by solving linear equations system in the main model.

\section{Model Result Analysis}

When carrying out policy evaluation using China's agricultural CGE model, two scenarios has been built, namely, the baseline scenario and policy scenarios. The baseline scenario refers to how the economic variables changed under no policy conditions. Policy scenario refers to how the economic variables changed with the policy under the baseline scenario. The difference gap between baseline scenario and policy scenarios is the effect of a policy change. In the baseline scenario, the simulation gives the overview of macroeconomic and agricultural sector impact analysis before policy simulation scenario. Baseline scenario formed by historical and forecast simulations. Therefore, the baseline simulation refers to the historical fit of 2002-2020 and the forecast fitting of 2020-2030 based on the 2002 input-output table database. Policy simulation shows the effects of a change in economic policy from the baseline scenario. The result of this paper focuses mainly on the difference between forecast simulation and policy simulation scenario to know the policy change impact on economy.

\subsection{Impact on Macro-economy}

CHINAGEM has dynamic equations that link the economies from one year to the next. In a policy simulation, the CGE model is informed of a change in a technology or policy variables, and the model calculates the resulting changes to GDP, consumption, output, employment and other endogenous variables. Technology 
augmentation can decrease production cost, price and price-related index such as export price index, investment price index and GDP price index. Compared with baseline, the main macroeconomic variables shows increasing trend and positively affects on overall macro-economy in China. The annual percentage changes in macroeconomic variables for the policy and forecast simulations are presented in Table 1. Table 1 show that China has the benefit of an average GDP growth of 7.9 percent from 2020 to 2030. By analyzing effects of a policy change Table 1 shows, GDP increases $0.017 \%$ and $0.005 \%$ in 2022 and 2024 followed by slight decrease in 2028 and 2030 compared to baseline. Employment increases $0.023 \%, 0.017 \%, 0.013 \%$ and $0.008 \%$ in 2022 , 2024, 2026 and 2030; real wages increases $0.38 \%$ and $0.011 \%$ in 2022 and 2024, and decreases $0.009 \%$ and $0.012 \%$ in 2028 and 2030 compared to baseline. Although employment is in increasing trend compared to baseline and this will affect disposable income positively. CPI decreases $0.04 \%$ and $0.004 \%$ in 2022,2024 , and increases small in degree in 2028 and 2030. Export follows the same pattern, increases $0.273 \%, 0.088 \%, 0.037 \%$, $0.013 \%, 0.004 \%$ in $2020,2022,2024,2026,2028$, and small decrease in 2030 compared to baseline. Import followed by decreasing trend with $0.023 \%, 0.014 \%, 0.01 \%, 0.006 \%$ and $0.005 \%$ in $2022,2024,2026,2028$, 2030 compared to baseline. The volume of exports is greater than the volume of imports contributing to China's current account surplus during this period. GDP growth in the policy scenario period is lower due to lower growth in employment. The lower growth in employment is due to a rapid reduction in the growth of working age population. Due to declining average propensity to consume, the policy scenario period continue to see slower growth in consumption.

Table 1. Model simulation, macro-economy impact (percentage changes)

\begin{tabular}{|c|c|c|c|c|c|c|c|}
\hline & & 2020 & 2022 & 2024 & 2026 & 2028 & 2030 \\
\hline \multirow[t]{3}{*}{ GDP } & Policy & 9.023 & 8.125 & 7.952 & 7.802 & 7.67 & 7.554 \\
\hline & Baseline & 8.289 & 8.108 & 7.947 & 7.802 & 7.673 & 7.558 \\
\hline & Difference & 0.734 & 0.017 & 0.005 & 0 & -0.003 & -0.004 \\
\hline \multirow[t]{3}{*}{ Employment } & Policy & -0.373 & 0.383 & 0.377 & 0.373 & 0.37 & 0.368 \\
\hline & Baseline & 0.36 & 0.36 & 0.36 & 0.36 & 0.36 & 0.36 \\
\hline & Difference & -0.733 & 0.023 & 0.017 & 0.013 & 0.01 & 0.008 \\
\hline \multirow[t]{3}{*}{$\mathrm{CPI}$} & Policy & 2.125 & 2.233 & 2.41 & 2.562 & 2.711 & 2.866 \\
\hline & Baseline & 2.125 & 2.273 & 2.414 & 2.554 & 2.697 & 2.851 \\
\hline & Difference & 0 & -0.04 & -0.004 & 0.008 & 0.014 & 0.015 \\
\hline \multirow[t]{3}{*}{ Real wage } & Policy & 9.117 & 7.55 & 7.2 & 6.878 & 6.577 & 6.296 \\
\hline & Baseline & 7.853 & 7.512 & 7.189 & 6.881 & 6.586 & 6.308 \\
\hline & Difference & 1.264 & 0.038 & 0.011 & -0.003 & -0.009 & -0.012 \\
\hline \multirow[t]{3}{*}{ Consumption } & Policy & 4.183 & 3.071 & 3.078 & 3.307 & 3.819 & 4.669 \\
\hline & Baseline & 3.228 & 3.081 & 3.094 & 3.325 & 3.837 & 4.685 \\
\hline & Difference & 0.955 & -0.01 & -0.016 & -0.018 & -0.018 & -0.016 \\
\hline \multirow[t]{3}{*}{ Export } & Policy & 11.699 & 10.816 & 10.124 & 9.486 & 8.863 & 8.219 \\
\hline & Baseline & 11.426 & 10.728 & 10.087 & 9.473 & 8.859 & 8.22 \\
\hline & Difference & 0.273 & 0.088 & 0.037 & 0.013 & 0.004 & -0.001 \\
\hline \multirow[t]{3}{*}{ Import } & Policy & 11.102 & 10.21 & 10.084 & 9.969 & 9.873 & 9.801 \\
\hline & Baseline & 10.378 & 10.233 & 10.098 & 9.979 & 9.879 & 9.806 \\
\hline & Difference & 0.724 & -0.023 & -0.014 & -0.01 & -0.006 & -0.005 \\
\hline
\end{tabular}

Source: Generated by author.

\subsection{Impact on Agricultural Sectors}

The Chinese economy experienced astonishing growth in the last few decades and agriculture sectors are in new era. Agriculture is a high-priority industry in China and China ranks first in worldwide farm output. The development and production of agricultural sector has played a significant role in supporting the economic growth of that country. Table 2 shows the output of agricultural sectors after augmenting technology. In terms of output of grain production under policy scenario; soybean, corn, wheat, rice, millet and vegetables production are in increasing trend, other agricultural crops are also in increasing trend after implementing policy in 2020. Baseline scenarios are also in increasing trend. Policy scenarios are compared to baseline forecasting scenario to know the policy change impact on economy and it shows soybean output increases $0.133 \%, 0.106 \%, 0.106 \%$, $0.122 \%$, and $0.127 \%$; Corn output decreases $0.057 \%, 0.077 \%, 0.078 \%, 0.068 \%$ and $0.053 \%$; rice output 
decreases $0.027 \%, 0.03 \%, 0.027 \%, 0.019 \%$ and $0.002 \%$; millet output decreases $0.062 \%, 0.084 \%, 0.088 \%$, $0.084 \%$ and $0.075 \%$; vegetable output decreases $0.026 \%, 0.03 \%, 0.028 \%, 0.02 \%$ and $0.006 \%$ in 2022,2024 , 2026, 2028 and 2030. Meanwhile wheat output decreases $0.026 \%, 0.022 \%$ and $0.011 \%$ in 2022, 2024, 2026 and increases $0.009 \%$ and $0.039 \%$ in 2028 and 2030 compared to baseline. Other agricultural crops and apples are in increasing trend; and grapes and citrus are in decreasing trend compared to baseline after implementing policy shock in 2020 .

Table 2. Model simulation, agriculture output (percentage changes)

\begin{tabular}{|c|c|c|c|c|c|c|c|}
\hline $\mathrm{x} 1$ tot & & 2020 & 2022 & 2024 & 2026 & 2028 & 2030 \\
\hline \multirow[t]{3}{*}{1 Soybeans } & Policy & 14.644 & 1.991 & 2.104 & 2.283 & 2.53 & 2.84 \\
\hline & Baseline & 1.813 & 1.878 & 1.998 & 2.177 & 2.418 & 2.713 \\
\hline & Difference & 12.831 & 0.113 & 0.106 & 0.106 & 0.112 & 0.127 \\
\hline \multirow[t]{3}{*}{2 Corn } & Policy & 10.913 & 6.993 & 7.133 & 7.235 & 7.279 & 7.246 \\
\hline & Baseline & 6.846 & 7.05 & 7.21 & 7.313 & 7.347 & 7.299 \\
\hline & Difference & 4.067 & -0.057 & -0.077 & -0.078 & -0.068 & -0.053 \\
\hline \multirow[t]{3}{*}{3 Wheat } & Policy & 9.06 & 2.647 & 2.825 & 3.085 & 3.438 & 3.894 \\
\hline & Baseline & 2.561 & 2.673 & 2.847 & 3.096 & 3.429 & 3.855 \\
\hline & Difference & 6.499 & -0.026 & -0.022 & -0.011 & 0.009 & 0.039 \\
\hline \multirow[t]{3}{*}{4 Rice } & Policy & 7.525 & 3.62 & 3.893 & 4.195 & 4.516 & 4.846 \\
\hline & Baseline & 3.398 & 3.647 & 3.923 & 4.222 & 4.535 & 4.848 \\
\hline & Difference & 4.127 & -0.027 & -0.03 & -0.027 & -0.019 & -0.002 \\
\hline \multirow[t]{3}{*}{5 Millet } & Policy & 6.889 & 3.781 & 3.821 & 3.914 & 4.042 & 4.19 \\
\hline & Baseline & 3.818 & 3.843 & 3.905 & 4.002 & 4.126 & 4.265 \\
\hline & Difference & 3.071 & -0.062 & -0.084 & -0.088 & -0.084 & -0.075 \\
\hline \multirow[t]{3}{*}{6 Vegetables } & Policy & 7.89 & 4.225 & 4.557 & 4.892 & 5.216 & 5.514 \\
\hline & Baseline & 3.924 & 4.251 & 4.587 & 4.92 & 5.236 & 5.52 \\
\hline & Difference & 3.966 & -0.026 & -0.03 & -0.028 & -0.02 & -0.006 \\
\hline \multirow[t]{3}{*}{7 Apples } & Policy & 4.035 & 3.557 & 3.753 & 3.978 & 4.232 & 4.51 \\
\hline & Baseline & 3.366 & 3.54 & 3.742 & 3.971 & 4.227 & 4.51 \\
\hline & Difference & 0.669 & 0.017 & 0.011 & 0.007 & 0.005 & 0 \\
\hline \multirow[t]{3}{*}{8 Citrus } & Policy & 2.906 & 2.466 & 2.697 & 3.015 & 3.439 & 3.983 \\
\hline & Baseline & 2.328 & 2.482 & 2.707 & 3.023 & 3.446 & 3.992 \\
\hline & Difference & 0.578 & -0.016 & -0.01 & -0.008 & -0.007 & -0.009 \\
\hline \multirow[t]{3}{*}{9 Grapes } & Policy & 2.847 & 2.195 & 2.258 & 2.374 & 2.558 & 2.827 \\
\hline & Baseline & 2.183 & 2.207 & 2.271 & 2.387 & 2.571 & 2.841 \\
\hline & Difference & 0.664 & -0.012 & -0.013 & -0.013 & -0.013 & -0.014 \\
\hline \multirow[t]{3}{*}{10 Other Crops } & Policy & 5.754 & 5.036 & 5.141 & 5.241 & 5.31 & 5.32 \\
\hline & Baseline & 4.833 & 4.973 & 5.109 & 5.225 & 5.303 & 5.32 \\
\hline & Difference & 0.921 & 0.063 & 0.032 & 0.016 & 0.007 & 0 \\
\hline
\end{tabular}

Source: Generated by author.

Changes in investment in agriculture by sectors provide evidence of positive pattern in economy. Investment in soybeans, corn, wheat, rice, millet and vegetables are in increasing trend and increased significantly both baseline and policy scenarios. Compared with policy to baseline forecasting scenario, investment in soybean increases $2.294 \%, 1.477 \%, 0.951 \%, 0.614 \%$ and $0.399 \%$; corn investment increases $4.23 \%, 2.549 \%, 1.444 \%$, $0.811 \%$ and $0.465 \%$; wheat investment increases $2.848 \%, 1.872 \%, 1.217 \%, 0.789 \%$ and $0.513 \%$; rice investment increase $3.11 \%, 2.051 \%, 1.32 \%, 0.846 \%$ and $0.543 \%$; millet investment increases $3.449 \%, 2.23 \%, 1.419 \%$, $0.901 \%$ and $0.576 \%$; vegetable investment increases $3.215 \%, 2.111 \%, 1.345 \%, 0.847 \%$ and $0.535 \%$ in 2022 , 2024, 2026, 2028 and 2030 after policy implication in 2020 (see Table 3). 
Table 3. Model simulation, investment on agricultural sectors (percentage change)

\begin{tabular}{|c|c|c|c|c|c|c|c|}
\hline $\mathrm{x} 2$ tot & & 2020 & 2022 & 2024 & 2026 & 2028 & 2030 \\
\hline \multirow[t]{3}{*}{1 Soybeans } & Policy & -17.371 & 7.822 & 8.048 & 8.622 & 9.43 & 10.384 \\
\hline & Baseline & 4.539 & 5.528 & 6.571 & 7.671 & 8.816 & 9.985 \\
\hline & Difference & -21.91 & 2.294 & 1.477 & 0.951 & 0.614 & 0.399 \\
\hline \multirow[t]{3}{*}{2 Corn } & Policy & -31.259 & 12.746 & 11.459 & 10.839 & 10.741 & 11 \\
\hline & Baseline & 8.004 & 8.453 & 8.91 & 9.395 & 9.93 & 10.535 \\
\hline & Difference & -39.263 & 4.293 & 2.549 & 1.444 & 0.811 & 0.465 \\
\hline \multirow[t]{3}{*}{3 Wheat } & Policy & -24.306 & 8.751 & 8.745 & 9.13 & 9.798 & 10.653 \\
\hline & Baseline & 5 & 5.903 & 6.873 & 7.913 & 9.009 & 10.14 \\
\hline & Difference & -29.306 & 2.848 & 1.872 & 1.217 & 0.789 & 0.513 \\
\hline \multirow[t]{3}{*}{4 Rice } & Policy & -27.095 & $9.75^{--}$ & 9.534 & 9.688 & 10.134 & 10.793 \\
\hline & Baseline & 5.821 & 6.639 & 7.483 & 8.365 & 9.288 & 10.25 \\
\hline & Difference & -32.916 & 3.111 & 2.051 & 1.323 & 0.846 & 0.543 \\
\hline \multirow[t]{3}{*}{5 Millet } & Policy & -29.383 & 9.617 & 9.225 & 9.318 & 9.774 & 10.482 \\
\hline & Baseline & 5.415 & 6.168 & 6.995 & 7.899 & 8.873 & 9.906 \\
\hline & Difference & -34.798 & 3.449 & 2.23 & 1.419 & 0.901 & 0.576 \\
\hline \multirow[t]{3}{*}{6 Vegetables } & Policy & -27.736 & 10.339 & 10.007 & 10.036 & 10.365 & 10.921 \\
\hline & Baseline & 6.356 & 7.124 & 7.896 & 8.691 & 9.518 & 10.386 \\
\hline & Difference & -34.092 & 3.215 & 2.111 & 1.345 & 0.847 & 0.535 \\
\hline \multirow[t]{3}{*}{7 Apples } & Policy & 6.999 & 6.359 & 7.212 & 8.126 & 9.096 & 10.113 \\
\hline & Baseline & 5.663 & 6.446 & 7.279 & 8.172 & 9.127 & 10.134 \\
\hline & Difference & 1.336 & -0.087 & -0.067 & -0.046 & -0.031 & -0.021 \\
\hline \multirow[t]{3}{*}{8 Citrus } & Policy & 6.105 & 5.833 & 6.871 & 7.964 & 9.099 & 10.256 \\
\hline & Baseline & 4.998 & 5.936 & 6.939 & 8.007 & 9.127 & 10.274 \\
\hline & Difference & 1.107 & -0.103 & -0.068 & -0.043 & -0.028 & -0.018 \\
\hline \multirow[t]{3}{*}{9 Grapes } & Policy & 5.968 & 5.474 & 6.468 & 7.544 & 8.689 & 9.882 \\
\hline & Baseline & 4.714 & 5.591 & 6.551 & 7.598 & 8.724 & 9.904 \\
\hline & Difference & 1.254 & -0.117 & -0.083 & -0.054 & -0.035 & -0.022 \\
\hline \multirow[t]{3}{*}{10 Other Crops } & Policy & 8.27 & 6.919 & 7.599 & 8.342 & 9.137 & $9.99^{\circ}$ \\
\hline & Baseline & 6.358 & 7.009 & 7.688 & 8.408 & 9.183 & 10.023 \\
\hline & Difference & 1.912 & -0.09 & -0.089 & -0.066 & -0.046 & -0.033 \\
\hline
\end{tabular}

Source: Generated by author.

Changes in the output and investment reflect changes in employment. Overall employment in soybean, wheat, rice, millet and vegetables sectors are in decreasing trend, and employment in corn sector is in increasing trend both baseline and policy forecasting scenarios. Compared with policy to baseline forecasting simulation scenario, the employment of soybean increases $0.188 \%, 0.159 \%, 0.144 \%, 0.139 \%$ and $0.147 \%$; employment of wheat increases $0.078 \%, 0.054 \%, 0.046 \%, 0.051 \%$ and $0.07 \%$; employment of rice increases $0.086 \%, 0.051 \%, 0.033 \%$, $0.026 \%$ and $0.031 \%$; employment of vegetable increases $0.087 \%, 0.052 \%, 0.031 \%, 0.021 \%$ and $0.024 \%$ in 2022 , 2024, 2026, 2028 and 2030 after policy implication in 2020. Meanwhile employment of corn increase $0.07 \%$, $0.002 \%$ in 2022 and 2024, and decreases $0.031 \%, 0.042 \%, 0.038$ percent in 2026, 2028 and 2030; employment of millet increases $0.064 \%, 0.009 \%$ in 2022 and 2014 , and decreases by $0.018 \%, 0.029 \%$ and $0.032 \%$ in 2026 , 2028 and 2030 compared to baseline after policy implication in 2020 (see Table 4). 
Table 4. Model simulation, employment by industry (percentage changes)

\begin{tabular}{|c|c|c|c|c|c|c|c|}
\hline employ & & 2020 & 2022 & 2024 & 2026 & 2028 & 2030 \\
\hline \multirow[t]{3}{*}{1 Soybeans } & Policy & -20.014 & -4.511 & -4.407 & -4.234 & -3.995 & -3.694 \\
\hline & Baseline & -4.783 & -4.699 & -4.566 & -4.378 & -4.134 & -3.841 \\
\hline & Difference & -15.231 & 0.188 & 0.159 & 0.144 & 0.139 & 0.147 \\
\hline \multirow[t]{3}{*}{2 Corn } & Policy & -23.449 & 0.449 & 0.537 & 0.603 & 0.621 & 0.572 \\
\hline & Baseline & 0.178 & 0.379 & 0.535 & 0.634 & 0.663 & 0.61 \\
\hline & Difference & -23.627 & 0.07 & 0.002 & -0.031 & -0.042 & -0.038 \\
\hline \multirow[t]{3}{*}{3 Wheat } & Policy & -24.32 & -3.799 & -3.645 & -3.406 & -3.074 & -2.64 \\
\hline & Baseline & -3.997 & -3.877 & -3.699 & -3.452 & -3.125 & -2.71 \\
\hline & Difference & -20.323 & 0.078 & 0.054 & 0.046 & 0.051 & 0.07 \\
\hline \multirow[t]{3}{*}{4 Rice } & Policy & -25.505 & -2.805 & -2.571 & -2.301 & -2.008 & -1.704 \\
\hline & Baseline & -3.135 & -2.891 & -2.622 & -2.334 & -2.034 & -1.735 \\
\hline & Difference & -22.37 & 0.086 & 0.051 & 0.033 & 0.026 & 0.031 \\
\hline \multirow[t]{3}{*}{5 Millet } & Policy & -26.287 & -2.851 & -2.826 & -2.742 & -2.618 & -2.473 \\
\hline & Baseline & -2.964 & -2.915 & -2.835 & -2.724 & -2.589 & -2.441 \\
\hline & Difference & -23.323 & 0.064 & 0.009 & -0.018 & -0.029 & -0.032 \\
\hline \multirow[t]{3}{*}{6 Vegetables } & Policy & -25.223 & -2.16 & -1.876 & -1.583 & -1.295 & -1.027 \\
\hline & Baseline & -2.561 & -2.247 & -1.928 & -1.614 & -1.316 & -1.051 \\
\hline & Difference & -22.662 & 0.087 & 0.052 & 0.031 & 0.021 & 0.024 \\
\hline \multirow[t]{3}{*}{7 Apples } & Policy & -2.54 & -3.025 & -2.83 & -2.608 & -2.361 & -2.091 \\
\hline & Baseline & -3.214 & -3.037 & -2.838 & -2.613 & -2.364 & -2.09 \\
\hline & Difference & 0.674 & 0.012 & 0.008 & 0.005 & 0.003 & -0.001 \\
\hline \multirow[t]{3}{*}{8 Citrus } & Policy & -3.639 & -4.076 & -3.842 & -3.527 & -3.112 & -2.583 \\
\hline & Baseline & -4.218 & -4.057 & -3.83 & -3.518 & -3.104 & -2.574 \\
\hline & Difference & 0.579 & -0.019 & -0.012 & -0.009 & -0.008 & -0.009 \\
\hline \multirow[t]{3}{*}{9 Grapes } & Policy & -3.692 & -4.338 & -4.267 & -4.146 & -3.961 & -3.696 \\
\hline & Baseline & -4.356 & -4.322 & -4.251 & -4.131 & -3.947 & -3.682 \\
\hline & Difference & 0.664 & -0.016 & -0.016 & -0.015 & -0.014 & -0.014 \\
\hline \multirow[t]{3}{*}{10 Other Crops } & Policy & -0.973 & -1.701 & -1.587 & -1.481 & -1.408 & -1.394 \\
\hline & Baseline & -1.907 & -1.757 & -1.615 & -1.494 & -1.412 & -1.392 \\
\hline & Difference & 0.934 & 0.056 & 0.028 & 0.013 & 0.004 & -0.002 \\
\hline
\end{tabular}

Source: Generated by author.

\section{Conclusion and Policy Recommendation}

Agriculture technology is the key issue to certain the food security. Simulation result shows, if the technology improved by 25 percent it will reduce production cost, products prices and price index (export price, investment price, and GDP price), making the trade situation more significant. Investment and capital inputs increases, result in increases of employment, real wages, household disposable income, household and government consumption. The technology improvement will have positive impact on overall macro-economy in China. The policy for improving agricultural technology progress will intensify the labor transfer and increases the quantity of labor transfer. Employment in Soybean, Wheat, Rice, Millet and Vegetable sectors are worse compared to other agricultural sectors. Employment in these sectors will switch to other sector. There will be a few agricultural and food commodities that could experience significant decline in self-sufficiency, but they will not affect China's economy overall. Accompanying China's rapid economic growth and its rising importance in the global economy, China's agricultural and food as well as overall economy will also experience significant structural changes.

China will play a greater role in the world economy. Because of higher economic growth in China than in the rest of the world, China's GDP shares in the world will rise gradually. Agricultural and Food trade in other countries/regions with china will also increase rapidly in future. The successful growth in the agriculture sector facilitates the economic transition from agriculture to industry/services and from the rural to the urban economy. The growth in agricultural productivity enabled China to release its large pool of abundant rural labour, 
providing cheap labour for the nation to industrialize its economy. The agricultural technology industry in China has been growing leaps and bounds for the past decade, however in order to create a completely sustainable agricultural sector, more advancement and improvement are required. To meet challenge in future will require substantial and long-term efforts in technological innovation, economic restructuring, investments, seeking new resources and establishing strategic partnerships with major trade partners.

\section{Acknowledgements}

I would like to thanks project named "Open Laboratory of national agricultural policy analysis and decision support system" and "Construction of Portal and Platform of Agricultural Economic Theory, Policy Analysis and remote Scientific Research Environment" for the grant. I would also like to thank my mother Khodeja Khanam and Uncle Syed Mazharul Haque for their motivation to carry on my research activities. Finally I would like to thanks Professor Huang Delin for his assistance and instruction in conducting the study and manuscript preparation.

\section{References}

Dixon, P. B., \& Rimmer, M. T. (2002). Dynamic General Equilibrium Modelling for Forecasting and Policy: A Practical Guide and Documentation of MONASH. North-Holland Publishing Company, Amsterdam.

Dixon, P. B., Parmenter, B. R., Sutton, J., \& Vincent, D. P. (1982). ORANI: A Multisectoral Model of the Australian Economy. North-Holland Publishing Company, Amsterdam.

Harrison, W. J., \& Pearson, K. R. (1996). Computing Solutions for Large General Equilibrium Models Using GEMPACK. Computational Economics, 9, 83-127. https://doi.org/10.1007/BF00123638

Ianchovichina, E., Darwin, R., \& Shoemaker, R. (2001). Resource use and technological progress in agriculture: A dynamic general equilibrium analysis. Ecological Economics, 38, 275-291. https://doi.org/10.1016/ S0921-8009(01)00165-3

Jianli, L., Hongdong, G., \& Jiac, F. (2017). Technological innovation in agricultural co-operatives in China: Implications for agro-food innovation policies. Food Policy, 73, 19-33. https://doi.org/10.1016/j.foodpol. 2017.09.001

Jikun, H., \& Scott, R. (2009). China's Agriculture: Drivers of Changes and Implications to China and the Rest of the World. International Association of Agricultural Economists Conference, Beijing, China.

Jintao, Z., Tian, X., Yanyuan, Z., Xinglong, Y., Zhongqiong, Q., \& Tao, T. (2017). The Effects of Agricultural R\&D on Chinese Agricultural Productivity Growth: New Evidence of Convergence and Implications for Agricultural R\&D Policy. Canadian Journal of Agricultural Economics, 65(3), 453-475. https://doi.org/ 10.1111/cjag.12137

Justin, Y. L. (1999). Technological change and Agricultural household income distribution: Theory and evidence from China. The Australian Journal of Agricultural and Resource Economics, 43(2), 179-174. https://doi.org/10.1111/1467-8489.00075

Mai, Y., Dixon, P. B., \& Rimmer, M. (2010). CHINAGEM: A Monash-Styled Dynamic CGE Model of China. Centre of Policy Studies Monash University, General Paper No. G-20.

Po-Chi, C., Ming-Miin, Y., Ching-Cheng, C., \& Shih-Hsun, H. (2008). Total factor productivity growth in China's agricultural sector. China Economic Review, 19, 580-593. https://doi.org/10.1016/j.chieco.2008. 07.001

Roos, E. L., Adams, P. D., \& Heerden, J. H. van. (2014). Constructing a CGE Database Using GEMPACK for an African Country. Computational Economics, 46(4), 495-518. https://doi.org/10.1007/s10614-014-9468-1

Sahoo, A., Shiferaw, B., \& Gbegbelegbe, S. (2016). A CGE Analysis of the Implications of Technological Change in Indian Agriculture. PEP working paper serie 2016-16. SSRN. https://doi.org/10.2139/ssrn. 3167234

Wang, H., \& Maosheng, R., (2014). CGE Simulation Analysis on the Labor Transfer, Agricultural Technical Progress, and Economic Development in Chongqing. Scientific World Journal, 2014, 148479. https://doi.org/10.1155/2014/148479

Yifu, L. J. (1999). Technological change and agricultural household income distribution: Theory and evidence from China. The Australian Journal of Agricultural and Resource Economics, 43(2), 179-194. https://doi.org/10.1111/1467-8489.00075 


\section{Copyrights}

Copyright for this article is retained by the author(s), with first publication rights granted to the journal.

This is an open-access article distributed under the terms and conditions of the Creative Commons Attribution license (http://creativecommons.org/licenses/by/4.0/). 